Sains Malaysiana 46(10)(2017): 1913-1921

http://dx.doi.org/10.17576/jsm-2017-4610-30

\title{
Perbandingan Zon Interaksi Ruang Dua Dimensi Subjek Normal dan Ambliopia Anisometropik
}

(Comparison of Two Dimension Spatial Interaction Zones between Normal Vision and Anisometropic Amblyopia)

\author{
MOHD IZZUDDIN HAIROL*, NORAZIZAH ABD LATIF, WOI PUI JUAN, \\ NURUL HAFIZAH AHMAD RASHAIDI \& SHARANJEET-KAUR
}

\begin{abstract}
ABSTRAK
Akuiti visual subjek ambliopia anisometropik sering disimulasi pada individu normal dengan mengkaburkan penglihatan fovea mereka. Walau bagaimanapun, prestasi akuiti visual periferi subjek ini tidak diketahui dan kaedah pengkaburan ini tidak semestinya dapat mensimulasi penglihatan periferi mereka. Untuk mendalami ketepatan kaedah ini, kami mengkaji akuiti dan bentuk zon interaksi ruang di fovea dan periferi retina subjek normal dan ambliopia anisometropik serta kesan pengkaburan pada akuiti subjek normal pada esentrisiti retina yang berbeza untuk dibandingkan dengan periferi subjek ambliopia. Akuiti diukur menggunakan Kaedah Rangsangan Malar untuk huruf Sheridan-Gardiner pada 6 orang subjek normal dan 6 orang subjek ambliopia anisometropik. Kesan kesesakan diukur dengan membandingkan respons pengesanan huruf sasaran yang diapit oleh huruf lain yang diletakkan pada orientasi mendatar, menegak dan pepenjuru. Rangsangan dipaparkan pada fovea dan 2.5, 5 dan 10 darjah di medan penglihatan inferior. Selain itu, akuiti fovea 4 orang subjek normal dikaburkan supaya sepadan dengan akuiti fovea subjek ambliopia menggunakan kaedah pengkaburan optik dan penuras digital Gaussian. Subjek normal menunjukkan kemerosotan akuiti yang lebih besar dengan peningkatan esentrisiti retina $\left(E_{2}: 2.25 \pm 0.21\right)$ berbanding subjek ambliopia anisometropik $\left(E_{2}: 6.02 \pm 1.45\right)$. Kesemua subjek menunjukkan zon interaksi ruang yang tidak simetri di kesemua esentrisiti retina yang diuji. Interaksi antara jenis kabur dan esentrisiti retina adalah signifikan $F(2.13,6.38)=4.93, \mathrm{p}=0.049)$ tetapi akuiti subjek normal yang dikaburkan dengan kedua-dua kaedah pengkaburan tidak berbeza secara signifikan dengan akuiti subjek ambliopia. Zon interaksi ruang subjek ambliopia anisometropik adalah sama dengan subjek normal. Akuiti fovea subjek ambliopia anisometropik lebih teruk berbanding subjek normal kerana peningkatan pengkaburan intrinsik. Walau bagaimanapun, periferi subjek ambliopia adalah normal secara fungsian.
\end{abstract}

Kata kunci: Ambliopia anisometropik; kesan kesesakan; pengkaburan; penglihatan fovea; penglihatan periferi

\section{ABSTRACT}

Visual acuity of anisometropic amblyopes is often simulated in visually normal individuals by imposing blur on their foveal vision. However, their peripheral visual acuity and whether the same method can simulate their peripheral vision are unknown. We examined: acuity and shape of spatial interaction zones at the fovea and in the periphery, in normal participants and anisometropic amblyopes; and the effect of imposed blur on acuity at different eccentricities in normal participants to compare with the amblyopic periphery. Acuity was measured with Method of Constant Stimuli using Sheridan-Gardiner letters in 6 normal and 6 amblyopic participants. Crowding was assessed by comparing performance for a letter flanked by other letters placed at horizontal, vertical and oblique orientations. Stimuli were presented foveally and at 2.5, 5 and 10 degrees in the lower visual field. In addition, foveal acuity of 4 normal participants was blurred to match the mean amblyopic acuity using Gaussian and optical defocus. Acuity was then re-measured across the lower visual field. Normal participants showed larger acuity deterioration with increasing eccentricity $\left(E_{2}\right.$ of $\left.2.25 \pm 0.21\right)$ than did anisometropic amblyopes $\left(E_{2}\right.$ of $\left.6.02 \pm 1.45\right)$. Both groups exhibited asymmetric crowding regions at all locations. Acuity was worse with optical blur compared to with Gaussian blur (significant blur type and eccentricity interaction, $F(2.13,6.38)=4.93, \mathrm{p}=0.049)$ but neither was significantly different from the acuity of amblyopes. Anisometropic amblyopia demonstrated similar asymmetric crowding regions to those found in normal vision, i.e. generally larger crowding for arrangements radial to the fixation point. Foveal acuity in anisometropic amblyopia was worse due to increased intrinsic blur relative to normal vision; however, their periphery appeared to be functionally normal.

Keywords: Anisometropic amblyopia; blur; crowding effect; foveal vision; peripheral vision

\section{PENGENALAN}

Ambliopia merupakan masalah perkembangan yang menjejaskan penglihatan ruang dan stereopsis dan sering melibatkan keadaan strabismus, anisometropia atau gabungan kedua-duanya pada peringkat bayi atau kanak-kanak (Ciuffreda et al. 1991). Secara amnya, 
seseorang individu dikelaskan sebagai anisometropik apabila terdapat perbezaan ralat refraksi melebihi 1 diopter antara kedua-dua mata. Prevalens anisometropia dalam populasi dilaporkan sekitar 10\% (Saw et al. 2008). Ambliopia dilaporkan menjadi salah satu punca kepada penyebab masalah penglihatan dalam kalangan kanakkanak Malaysia (Hussin et al. 2009). Oleh itu, kajian melibatkan anisometropia adalah penting kerana prelavens dan tahap keterukan ambliopia berkait rapat dengan tahap anisometropia (Tanlamai \& Goss 1979; Weakley 2001). Cara untuk merawat ambliopia adalah dengan pengesanan awal, pembetulan ralat refraktif dan ketidakselarian paksi visual serta pengatupan mata dominan untuk memberi peluang kepada mata ambliopia untuk menerima rangsangan. Keberkesanan atau prognosis rawatan ini bergantung kepada seawal mana pesakit dirujuk kepada pengamal optometri dan jenis ambliopia yang dihidapi oleh pesakit (Kaur et al. 2011).

Pesakit ambliopia anisometropik dilaporkan memiliki kabur intrinsik yang lebih besar daripada individu normal (Levi \& Klein 1990). Kabur intrinsik adalah jumlah kabur yang apabila digabungkan dengan kabur rangsangan akan menghasilkan kabur efektif rangsangan tersebut. Dalam kes ambliopia anisometropik, pengalaman visual mereka merangkumi satu imej retina yang tidak terfokus dan ini menyebabkan peningkatan kabur intrinsik. Dalam erti kata lain, penglihatan fovea pesakit ambliopia anisometropik adalah lebih merosot (iaitu lebih kabur) daripada penglihatan fovea normal semata-mata kerana magnitud kabur intrinsik yang besar pada penglihatan fovea mereka dan kesan ini tetap wujud meskipun kabur rangsangan diminima dan dimalarkan. Walau bagaimanapun, tidak diketahui sekiranya periferi retina pesakit ambliopia anisometropik juga mengalami peningkatan kabur intrinsik seperti yang dicadangkan untuk penglihatan fovea mereka.

Satu ciri klinikal yang boleh membezakan pesakit berpenglihatan normal dan pesakit ambliopia anisometropik adalah kewujudan kesan kesesakan. Kesan kesesakan adalah suatu fenomena yang penting dalam persepsi penglihatan. Apabila sesuatu rangsangan dikelilingi oleh objek yang lain, kebolehan seseorang untuk mengenal pasti objek tersebut merosot. Kesan ini berlaku untuk pelbagai jenis rangsangan seperti huruf, nombor dan gratings (Bouma 1970; Hairol et al. 2015, 2013; Strasburger et al. 1991; Stuart \& Burian 1962). Kesan kesesakan boleh bertambah dengan meningkatkan jumlah objek yang mengelilingi rangsangan tersebut (Felisberti et al. 2005) dan kedudukan (esentrisiti) rangsangan yang menjauhi retina (Bouma 1970; Jacobs 1979) atau pun dengan mengurangkan jarak antara rangsangan dengan objek yang mengelilinginya (Flom et al. 1963). Mekanisme neural yang dikatakan bertanggungjawab menyebabkan kesan kesesakan termasuklah perencatan lateral yang berlaku antara rangsangan dan objek sekitar (Bjork \& Murray 1977), pengumpulan ciri ruang yang kurang tepat (Parkes et al. 2001) dan resolusi tumpuan visual yang tidak mencukupi (Strasburger et al. 1991).
Objektif kajian ini adalah untuk memeta dan membandingkan zon interaksi ruang dua dimensi bagi subjek berpenglihatan normal dengan subjek ambliopia aniosmetropik. Pemetaan ini dicapai dengan menggunakan sasaran huruf yang diapit dengan huruf-huruf lain pada jarak dan kedudukan yang berbeza untuk mewujudkan kesan kesesakan. Kajian ini juga ingin menjawab hipotesis sejauh manakah penglihatan ambliopia anisometropik dapat dimimik dengan mengkaburi penglihatan subjek normal. Ia dicapai dengan pengkaburan secara optik menggunakan kanta positif, serta secara digital iaitu dengan menggunakan penuras digital Gaussian. Keputusan kajian ini dapat membantu kita untuk mendalami mekanisme penglihatan subjek ambliopia anisometropik dan sejauh manakah pemprosesan penglihatan subjek ini menyimpang daripada mekanisme penglihatan normal.

\section{BAHAN DAN KAEDAH}

\section{UJI KAJI 1: ZON INTERAKSI RUANG SUBJEK NORMAL DAN} AMBLIOPIA ANISOMETROPIK

Rangsangan yang digunakan adalah huruf Sheridan Gardiner (A, H, O, T, U, V dan X). Ia pada kontras $98 \%$. Rangsangan ini dibina menggunakan templat $5 \times 5$ sebagai matriks dan dikawal dalam perisian Matlab (Mathworks, USA) dan pengaturcaraan Psychtoolbox (Brainard 1997) menggunakan Apple iMac dengan sistem pengoperasian OSX. Rangsangan kemudiannya dipaparkan pada monitor CRT Samsung dengan frekuensi $150 \mathrm{~Hz}$. Luminans min monitor adalah $53 \mathrm{~cd} / \mathrm{m}^{2}$. Monitor ini dikalibrasi menggunakan fotometer ColorCal (Cambridge Research Systems). Sebuah papan kekunci tanpa wayar digunakan untuk merekodkan respons subjek.

Nilai ambang akuiti untuk huruf tunggal ditentukan menggunakan kaedah rangsangan malar dan prosedur tujuh alternatif pilihan paksa. Tujuh saiz huruf berbeza dipaparkan secara rawak dalam 400 cubaan untuk menghasilkan fungsi psikometrik. Subjek memberikan respons dengan menekan satu butang pada papan kekunci. Masa paparan rangsangan tidak dihadkan. Untuk subjek normal, uji kaji dijalankan pada mata dominan manakala mata satu lagi ditutup menggunakan pengatup legap. Untuk subjek ambliopia, uji kaji dijalankan pada mata ambliopik. Nilai ambang akuiti huruf tunggal ini ditentukan pada empat lokasi retina berbeza iaitu darjah sifar (fovea) dan di periferi retina pada 2.5 darjah, 5 darjah dan 10 darjah di medan penglihatan inferior. Pengukuran nilai ambang di periferi retina dilakukan dengan mengarahkan pesakit melihat sasaran fiksasi yang dipaparkan di bahagian tengah monitor. Ketepatan fiksasi tidak dipantau tetapi sebarang ralat akibat fiksasi boleh ditentukan dengan melihat kepada corak keputusan akhir kajian.

Data purata untuk setiap subjek dipadankan dengan keluk Weibull mengikut formula berikut:

$$
P_{(\text {correct })}(s)=\left(1-(1-g) \times \exp \left(-10^{\beta(s-t h)}\right),\right.
$$


dengan th adalah nilai ambang akuiti dalam unit logMAR pada $69 \%$ respons betul; $g$ adalah kebarangkalian tekaan (14.7\%); $\beta$ adalah kecerunan fungsi psikometrik; dan $s$ adalah saiz sasaran dalam unit logMAR.

Nilai $\mathrm{E}_{2}$, iaitu lokasi periferi retina dan nilai ambang akuiti adalah dua kali ganda berbanding nilai ambang akuiti fovea (Levi et al. 1985) dihitung dengan plot ambang akuiti (dalam unit MAR) lawan esentrisiti menggunakan formula berikut:

$$
T=T_{f} \times\left(1+\frac{E}{E_{2}}\right),
$$

dengan $T$ adalah nilai ambang akuiti pada esentrisiti E; dan $T_{f}$ adalah nilai ambang akuiti fovea.

Setelah nilai ambang akuiti untuk huruf tunggal diperoleh pada setiap lokasi retina yang diuji, saiz sasaran ditingkatkan supaya kadar ketepatan respons subjek meningkat kepada sekitar 90-95\%. Ketepatan respons diuji semula, kali ini dengan dua huruf lain diletakkan pada jarak $0,0.25,0.50,0.75,1.0$ dan 2.0 kali saiz huruf daripada sasaran. Huruf-huruf ini bertindak sebagai bentuk kesesakan dan diletakkan pada kedudukan mendatar, menegak atau pepenjuru kepada sasaran seperti yang ditunjukkan dalam Rajah 1. Rangsangan ini dipaparkan pada empat lokasi retina yang berbeza iaitu di fovea, 2.5 darjah, 5 darjah dan 10 darjah di medan penglihatan inferior. Data kemudian dipadankan dengan keluk Gaussian dan nilai tiga sisihan piawai keluk Gaussian tersebut diambil sebagai jarak kesan kesesakan.

Enam orang subjek normal (min umur $24.50 \pm 3.02$ tahun) dan enam orang subjek ambliopia anisometropik (min umur $18.83 \pm 2.56$ tahun) terlibat dalam Uji Kaji 1 . Kesemua subjek normal mempunyai akuiti penglihatan logMAR (logaritma sudut resolusi minimum) atau lebih baik. Subjek ambliopia anisometropik dikenal pasti melalui rekod di Klinik Optometri, Universiti Kebangsaan Malaysia. Perincian subjek ambliopia anisometropik

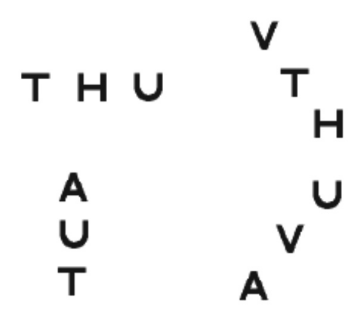

RAJAH 1. Susunan rangsangan yang digunakan dalam penentuan jarak kesan kesesakan. Huruf sasaran adalah huruf tengah yang diapit sama ada secara mendatar (atas kiri); menegak (bawah kiri); pepenjuru kiri (atas kanan); dan pepenjuru kanan (bawah kanan)

dipaparkan dalam Jadual 1. Etika penyelidikan ini telah diluluskan oleh Jawatankuasa Etika Penyelidikan, Universiti Kebangsaan Malaysia. Keizinan subjek telah diperoleh secara bertulis sebelum pengumpulan data dimulakan.

\section{UJI KAJI 2: AKUITI PERIFERI SUBJEK NORMAL YANG DIKABURKAN PENGLIHATAN}

Dalam uji kaji ini, nilai ambang akuiti diukur untuk rangsangan yang dikaburkan pada empat orang subjek normal. Rangsangan dikaburkan menjadi simulasi kepada penglihatan ambliopia anisometropik. Pengkaburan dicapai melalui dua kaedah iaitu dengan meletakkan kanta optik positif di hadapan mata yang diuji; dan menuras imej secara digital (pengaturacaraan) dengan menggunakan penuras Gaussian dan jumlah kabur ditentukan dengan menurunkan nilai sisihan piawai penuras Gaussian tersebut. Untuk kedua-dua keadaan pengkaburan, nilai kuasa kanta dan sisihan piawai penuras Gaussian dipilih supaya akuiti penglihatan fovea subjek Uji Kaji 2 tidak berbeza secara signifikan dengan akuiti penglihatan fovea subjek ambliopia anisometropik daripada Uji Kaji 1.

JADUAL 1. Ciri-ciri klinikal subjek ambliopia anisometropik dalam Uji Kaji 1

\begin{tabular}{|c|c|c|c|c|c|}
\hline Subjek & Umur & Jantina $^{\mathrm{a}}$ & Mata & Preskripsi & Akuiti (logMAR) ${ }^{\mathrm{b}}$ \\
\hline NS & 18 & $\mathrm{P}$ & $\begin{array}{l}\text { Kanan } \\
\text { Kiri }\end{array}$ & $\begin{array}{l}-4.75 /-0.25 \times 170 \\
-5.00 /-0.50 \times 5\end{array}$ & $\begin{array}{c}0.24 \\
0\end{array}$ \\
\hline $\mathrm{NH}$ & 17 & $\mathrm{~L}$ & $\begin{array}{l}\text { Kanan } \\
\text { Kiri }\end{array}$ & $\begin{array}{l}-12.00 /-2.00 \times 5 \\
-0.50 /-5.00 \times 5\end{array}$ & $\begin{array}{c}0.42 \\
0\end{array}$ \\
\hline $\mathrm{HSH}$ & 23 & $\mathrm{~L}$ & $\begin{array}{l}\text { Kanan } \\
\text { Kiri }\end{array}$ & $\begin{array}{l}-11.25 /-4.50 \times 5 \\
-10.00 /-4.25 \times 170\end{array}$ & $\begin{array}{l}0.34 \\
0.26\end{array}$ \\
\hline SY & 21 & $\mathrm{~L}$ & $\begin{array}{l}\text { Kanan } \\
\text { Kiri }\end{array}$ & $\begin{array}{l}-1.75 /-2.50 \times 40 \\
-6.00 /-4.00 \times 135\end{array}$ & $\begin{array}{c}0 \\
0.22\end{array}$ \\
\hline GR & 17 & $\mathrm{~L}$ & $\begin{array}{l}\text { Kanan } \\
\text { Kiri }\end{array}$ & $\begin{array}{l}-6.00 /-3.00 \times 33 \\
-2.75 /-3.00 \times 140\end{array}$ & $\begin{array}{l}0.22 \\
0.12\end{array}$ \\
\hline HR & 17 & $\mathrm{~L}$ & $\begin{array}{l}\text { Kanan } \\
\text { Kiri }\end{array}$ & $\begin{array}{l}-5.25 /-1.50 \times 35 \\
-8.25 /-2.25 \times 155\end{array}$ & $\begin{array}{l}0.12 \\
0.22\end{array}$ \\
\hline
\end{tabular}

${ }^{\mathrm{a}} \mathrm{L}$ : lelaki; P: Perempuan

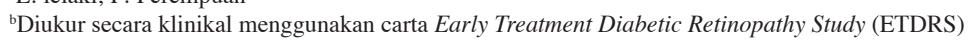


Nilai ambang akuiti penglihatan diukur menggunakan huruf Sheridan Gardiner yang dipaparkan secara tunggal pada esentrisiti retina 0 (di fovea), 2.5 darjah, 5 darjah dan 10 darjah di medan penglihatan inferior. Data dikumpul secara tersusun untuk setiap keadaan pengkaburan iaitu dimulakan dengan tanpa pengkaburan, diikuti dengan kabur optik dan kabur Gaussian. Kesemua prosedur uji kaji lain adalah seperti yang telah diterangkan untuk Uji Kaji 1.

\section{KEPUTUSAN DAN PERBINCANGAN}

\section{UJI KAJI 1}

Akuiti visual untuk huruf tunggal dalam unit logMAR diplot melawan esentristi retina untuk subjek normal dan subjek ambliopia anisometropik dan dipaparkan dalam Rajah 2. Untuk kedua-dua kumpulan subjek, akuiti visual merosot dengan peningkatan esentrisiti retina. Akuiti fovea subjek ambliopia anisometropik $(0.09 \pm 0.04$ logMAR $)$ adalah lebih teruk berbanding subjek normal $(-0.20 \pm 0.03 \log M A R)$, iaitu merosot kira-kira tiga barisan pada carta huruf. Nilai ambang akuiti kedua-dua kumpulan subjek adalah lebih serupa dengan peningkatan esentrisiti retina. Analisis ANOVA 2-hala antara kumpulan menunjukkan terdapat interaksi yang signifikan antara kumpulan subjek dan esentrisiti $\left[\mathrm{F}_{(3,40)}=5.589, p=0.03\right]$, iaitu kesan esentrisiti terhadap nilai ambang akuiti adalah berbeza bergantung kepada kumpulan subjek.

Kesan peningkatan esentrisiti retina terhadap akuiti visual diukur menggunakan nilai $\mathrm{E}_{2}$. Nilai $\mathrm{E}_{2}$ adalah lebih kecil untuk subjek normal (min: $2.25 \pm 0.21$ ) berbanding subjek ambliopia anisometropik (min: 6.02 \pm 1.45 ). Perbezaan ini adalah signifikan secara statistik $\left[\mathrm{t}_{(10)}\right.$ $=-2.57, p=0.03]$ dan ia memberi indikasi bahawa kemerosotan akuiti yang lebih tinggi dengan peningkatan esentrisiti retina untuk subjek normal. Dalam erti kata lain, perubahan esentrisiti kira-kira 2 darjah menyebabkan akuiti fovea subjek normal meningkat sebanyak dua kali ganda, berbanding dengan perubahan esentrisiti kira-kira 6 darjah untuk subjek ambliopia anisometropik mencapai perubahan akuiti dalam magnitud yang sama (dua kali ganda berbanding akuiti fovea).

Rajah 3 dan 4 masing-masing menunjukkan zon interaksi ruang pada medan penglihatan untuk setiap subjek normal dan ambliopia anisometropik. Terdapat variasi daripada segi saiz dan bentuk interaksi pada setiap individu. Dengan peningkatan esentrisiti, saiz zon interaksi ini bertambah dan bentuknya memanjang secara jejarian ke arah fovea. Pada skala ini, saiz zon interaksi kelihatan serupa untuk kedua-dua kumpulan subjek. Ciri kualitatif zon interaksi ini adalah hampir sama seperti yang telah dilaporkan untuk subjek normal sebelum ini (Toet \& Levi 1992).

Jadual 2 menunjukkan purata jarak kesan kesesakan yang ditentukan daripada padanan keluk Gaussian pada data ketepatan respons. Jarak kesan kesesakan ini ditentukan pada setiap esentrisiti retina yang diuji untuk setiap susunan rangsangan (mendatar, menegak dan pepenjuru). Untuk kedua-dua kumpulan subjek, jarak kesan kesesakan mendatar adalah lebih besar daripada menegak (nisbah mendatar-menegak lebih daripada 1) untuk fiksasi fovea. Jarak kesesakan mendatar untuk kumpulan ambliopia adalah lebih besar daripada kumpulan normal tetapi perbezaan ini tidak signifikan daripada segi statistik. Pada esentrisiti retina 2.5, 5.0 dan 10.0 darjah, jarak kesesakan mendatar adalah lebih kecil daripada menegak (nisbah mendatar-menegak kurang daripada 1).

Perbezaan antara nisbah jarak kesesakan mendatar dan menegak dapat dilihat dengan lebih jelas dalam Rajah 5. Dalam rajah ini, zon interaksi pada setiap esentrisiti diplot bersama dengan titik tengah mewakili huruf tengah pada rangsangan. Pada skala ini, jarak kesesakan yang diukur di fovea adalah lebih ketara untuk subjek ambliopia anisometropik. Pada esentrisiti retina selain fovea, jarak kesesakan memanjang secara menegak. Zon interaksi ruang yang tidak simetri telah dilaporkan dalam kajian terdahulu untuk subjek normal (Feng et al. 2007; Toet \& Levi 1992) tetapi kajian ini menunjukkan zon interaksi
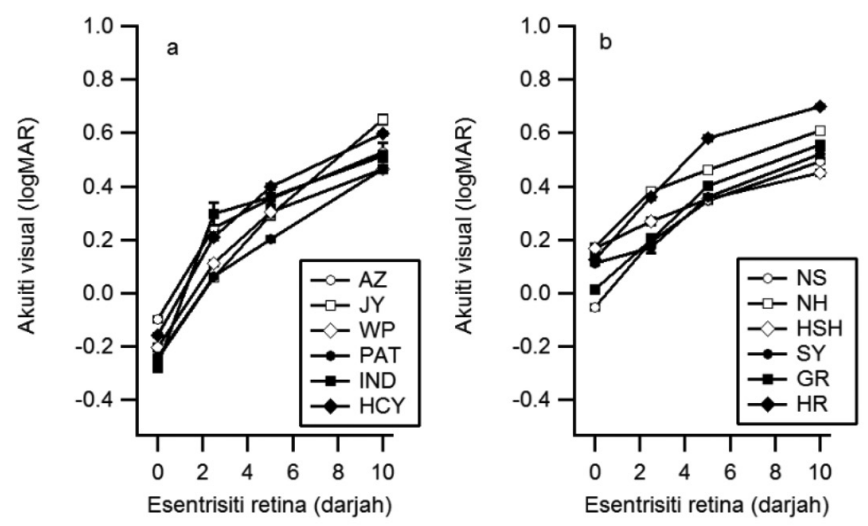

RAJAH 2. Akuiti visual (unit logMAR) untuk huruf tunggal diplot melawan esentrisiti retina (unit darjah) untuk subjek (a) normal dan (b) ambliopia anisometropik 

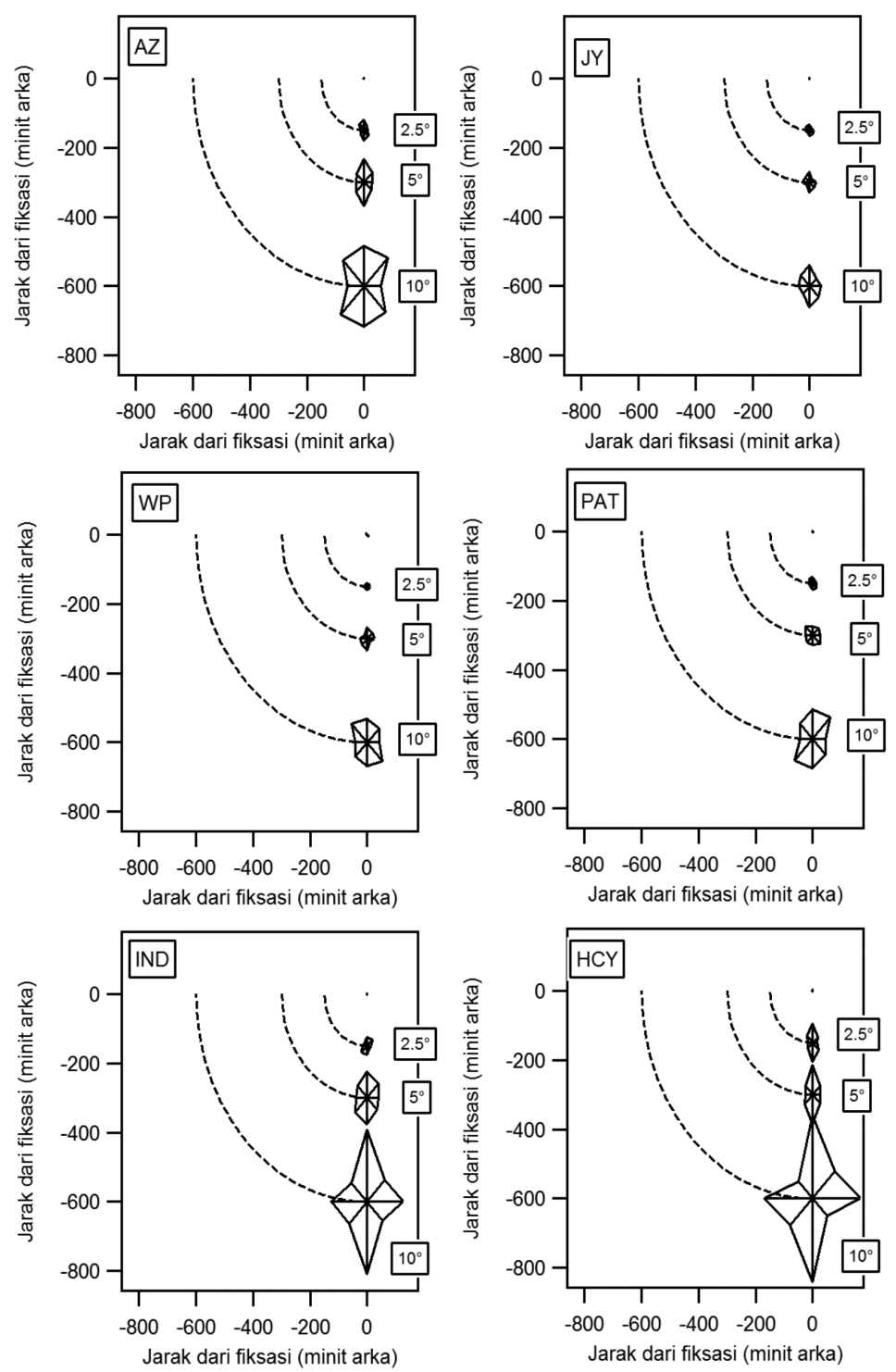

RAJAH 3. Peta jarak kesan kesesakan pada empat esentrisiti retina berbeza $(0,2.5,5$ dan 10 darjah di medan penglihatan periferi) untuk empat orientasi rangsangan (mendatar, menegak, pepenjuru kanan dan pepenjuru kiri) bagi subjek normal

ruang bagi subjek ambliopia anismetropik adalah serupa secara kualitatif dengan subjek normal.

Satu faktor yang mungkin menyumbang kepada asimetri mendatar-menegak ini adalah kesemua subjek membaca secara mendatar. Mekanisma penumpuan penglihatan cenderung untuk mengumpulkan objek yang tersusun secara mendatar sebagai satu unit, berbanding dengan objek yang tersusun secara menegak. Ini boleh menyebabkan integrasi mendatar yang lebih kuat berbanding menegak dan mempengaruhi kesan jarak kesesakan.

\section{UJI KAJI 2}

Rajah 6 menunjukkan akuiti visual dalam unit logMAR yang diplot melawan esentrisiti retina untuk empat subjek normal yang dikaburkan secara optik dan menggunakan penuras Gaussian. Untuk kedua-dua kaedah pengkaburan, akuiti visual merosot seiring dengan peningkatan esentrisiti retina. Ujian ANOVA pengukuran berulang dengan pembetulan Greenhouse-Geisser menunjukkan kesan jenis pengkaburan terhadap akuiti visual adalah tidak signifikan $[\mathrm{F}(1,3)=7.96, p=0.07]$. Tahap esentrisiti retina memberi kesan yang amat signifikan terhadap akuti visual $[\mathrm{F}(1.72,5.17)=79.18, p<0.001]$. Akuiti adalah lebih teruk apabila diukur dengan kabur optik berbanding kabur digital Gaussian tetapi kedua-duanya tidak berbeza secara signifikan dengan akuiti ambliopia anisometropik $\mathrm{F}(2.13,6.38)=4.93, p=0.049]$.

Jadual 3 membandingkan nilai $\mathrm{E}_{2}$ subjek normal daripada Uji Kaji 1 dengan data yang diperoleh daripada tiga kumpulan subjek daripada Uji Kaji 2. Nilai $E_{2}$ tidak berbeza secara signifikan antara subjek ambliopia anisometropik dengan subjek normal yang dikaburkan secara optik $\left[\mathrm{t}_{(8)}=0.50, p=0.63\right]$ dan dengan subjek normal 

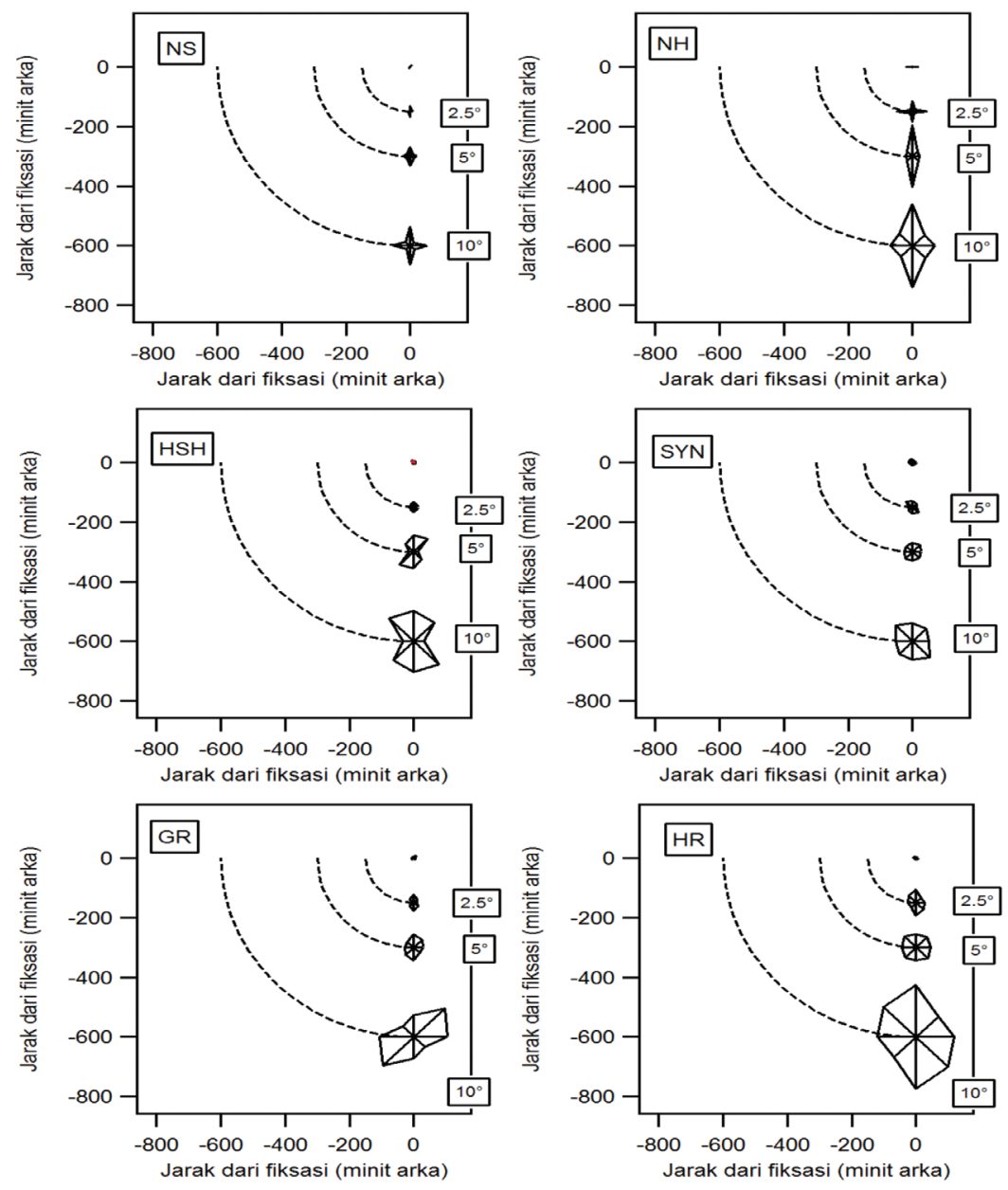

RAJAH 4. Peta jarak kesan kesesakan pada empat esentrisiti retina berbeza $(0,2.5,5$ dan 10 darjah di medan penglihatan periferi) untuk empat orientasi rangsangan (mendatar, menegak, pepenjuru kanan dan pepenjuru kiri) bagi subjek ambliopia anisometropik

JADUAL 2. Purata( \pm ralat piawai) jarak kesan kesesakan dalam unit minit arka untuk huruf sasaran yang diapit dengan huruf lain dalam susunan mendatar, menegak dan pepenjuru pada empat esentrisiti retina yang berbeza. Jarak ini ditentukan melalui plot keluk Gaussian pada data ketepatan respons. Nisbah jarak kesesakan mendatar-menegak ditunjukkan dalam ruang paling kanan

\begin{tabular}{|c|c|c|c|c|c|}
\hline \multirow{2}{*}{$\begin{array}{l}\text { Esentrisiti retina } \\
\text { (darjah) }\end{array}$} & \multicolumn{4}{|c|}{ Susunan rangsangan (sasaran dan huruf kesesakan) } & \multirow{2}{*}{$\begin{array}{l}\text { Nisbah mendatar } \\
\text { menegak }\end{array}$} \\
\hline & Mendatar & Menegak & Pepenjuru kanan & Pepenjuru kiri & \\
\hline \multicolumn{6}{|l|}{ Normal } \\
\hline 0 & $2.62 \pm 0.44$ & $1.87 \pm 0.36$ & $0 \pm 0$ & $0.97 \pm 0.70$ & $1.59 \pm 0.34$ \\
\hline 2.5 & $13.65 \pm 1.07$ & $25.64 \pm 6.60$ & $11.38 \pm 2.17$ & $12.48 \pm 2.06$ & $0.66 \pm 0.10$ \\
\hline 5 & $28.23 \pm 2.34$ & $53.00 \pm 10.68$ & $23.64 \pm 4.46$ & $22.35 \pm 3.53$ & $0.63 \pm 0.10$ \\
\hline 10 & $79.61 \pm 22.23$ & $129.71 \pm 31.20$ & $58.09 \pm 9.26$ & $51.72 \pm 5.84$ & $0.60 \pm 0.03$ \\
\hline \multicolumn{6}{|c|}{ Ambliopia anisometropik } \\
\hline 0 & $8.49 \pm 2.87$ & $4.77 \pm 1.28$ & $3.68 \pm 0.88$ & $3.67 \pm 1.28$ & $2.68 \pm 1.47$ \\
\hline 2.5 & $19.76 \pm 6.34$ & $26.71 \pm 4.42$ & $9.67 \pm 1.62$ & $11.48 \pm 3.56$ & $0.71 \pm 0.13$ \\
\hline 5 & $25.42 \pm 4.46$ & $57.00 \pm 11.84$ & $25.03 \pm 5.15$ & $20.87 \pm 3.80$ & $0.53 \pm 0.10$ \\
\hline 10 & $72.22 \pm 13.75$ & $102.25 \pm 18.84$ & $52.74 \pm 12.10$ & $53.35 \pm 12.84$ & $0.78 \pm 0.15$ \\
\hline
\end{tabular}

yang dikaburkan menggunakan penuras digital Gaussian $\left[\mathrm{t}_{(8)}=-1.18, \mathrm{p}=0.91\right]$.

Keputusan kajian ini mencadangkan bahawa kemerosotan penglihatan fovea subjek ambliopia anisometropik berlaku akibat peningkatan kabur intrinsik (Levi \& Klein 1990) berbanding subjek normal. Oleh itu, penggunaan kabur ke atas subjek normal, sama ada dengan menggunakan kabur optik atau kabur penuras 

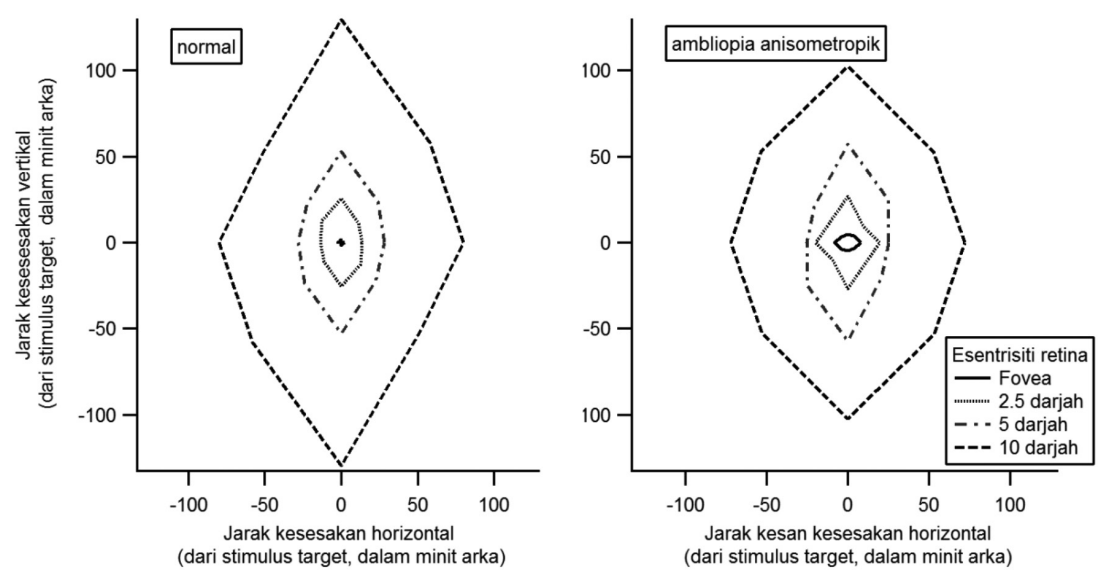

RAJAH 5. Peta jarak kesan kesesakan purata yang dibentuk daripada zon interaksi ruang untuk rangsangan yang dipaparkan pada esentrisiti retina $0,2.5,5$ dan 10 darjah di medan penglihatan inferior bagi subjek normal (panel kiri) dan subjek ambliopia anisometropik (panel kanan).

Peta ini dipaparkan pada titik tengah yang sama untuk setiap esentrisiti retina

JADUAL 3. Min dan ralat piawai nilai $\mathrm{E}_{2}$ untuk huruf yang dipaparkan secara tunggal untuk subjek normal (tanpa pengkaburan dengan pengkaburan digital Gaussian dan pengkaburan optik) serta subjek ambliopia anisometropik

\begin{tabular}{lc}
\hline Kumpulan subjek & Min $_{2} \pm$ SEM \\
\hline Normal tanpa pengkaburan (Uji Kaji 1) & $2.25 \pm 0.21$ \\
Normal dengan pengkaburan Gaussian & $6.25 \pm 0.78$ \\
Normal dengan pengkaburan optik & $5.06 \pm 0.86$ \\
Ambliopia anisometropik & $6.03 \pm 1.45$ \\
\hline
\end{tabular}

digital Gaussian, boleh digunakan sebagai model penglihatan fovea ambliopia anisometropik. Tetapi keputusan pada Rajah 6 menunjukkan ini hanya benar untuk penglihatan fovea sahaja. Periferi retina subjek ambliopia anisometropik menunjukkan prestasi yang sama dengan periferi retina subjek normal. Keputusan ini mencadangkan bahawa kawasan retina selain daripada fovea subjek ambliopia anisometropik berfungsi dengan normal dan tidak mengalami pertambahan kabur intrinsik. Apakah implikasi daripada keputusan kajian ini? Penglihatan periferi ambliopia anisometropik yang menunjukkan prestasi normal mencadangkan bahawa integriti pemprosesan penglihatan di kawasan luar fovea mereka tidak dipengaruhi oleh penglihatan kabur yang dialami di kawasan fovea. Oleh itu, kaedah terapi yang diamalkan pada masa ini seperti terapi pengatupan yang hanya memfokuskan kepada penglihatan fovea boleh diteruskan. Pengetahuan tentang aspek penglihatan perferi ambliopia juga boleh digunakan dalam aspek penglihatan yang lain, seperti perkembangan miopia. Salah satu teori kepada perkembangan miopia adalah defokus hiperopia yang berlaku di bahagian periferi retina. Defokus hiperopia dicadangkan sebagai penyumbang kepada pemanjangan aksial bola mata dan seterusnya meningkatkan magnitud miopia (Atchison et al. 2005; Mutti et al. 2007)25.5. Kajian ini secara tidak langsung mencadangkan proses perkembangan miopia, sekiranya berlaku pada subjek ambliopia anisometropik, adalah serupa sekurang- kurangnya di kawasan periferi retina. Pernyataan ini wajar dikaji dengan lebih mendalam dalam kajian akan datang. Antara limitasi kajian yang telah dikenal pasti adalah penggunaan kanta optik untuk mengkaburkan penglihatan subjek normal dan juga sebagai pembetulan refraksi subjek ambliopia anisometropik. Reka bentuk kanta oftalmik, termasuk kesan distorsi yang teraruh berbeza antara satu kanta dengan kanta yang lain. Ini mungkin memberi kesan kepada persepsi penglihatan subjek yang boleh mempengaruhi persepsi penglihatan mereka. Walau bagaimanapun, keputusan yang diperoleh adalah hampir serupa dalam kalangan subjek dan sebarang kesan akibat perbezaan kanta optik terhadap persepsi penglihatan subjek adalah minima. Limitasi kedua adalah pergerakan mata subjek tidak dikawal terutamanya semasa prestasi visual akuiti periferi diukur. Dalam kajian ini, subjek telah dilatih untuk mengekalkan fiksasi pada sasaran yang ditetapkan dan pengumpulan data hanya dimulakan setelah subjek faham akan prosedur uji kaji. Ketidakwujudan ketaknormalan dan konsistensi pada data meyakinkan kami bahawa pergerakan mata subjek meskipun tidak dikawal sepenuhnya hanya memberi pengaruh minimum pada keputusan uji kaji.

Dalam kajian akan datang, subjek boleh diberikan kanta oftalmik yang serupa untuk memastikan kesan reka bentuk kanta adalah malar. Kanta sentuh juga boleh digunakan sebagai pengganti kepada kanta oftalmik. Ralat refraksi subjek dalam julat tertentu juga boleh 


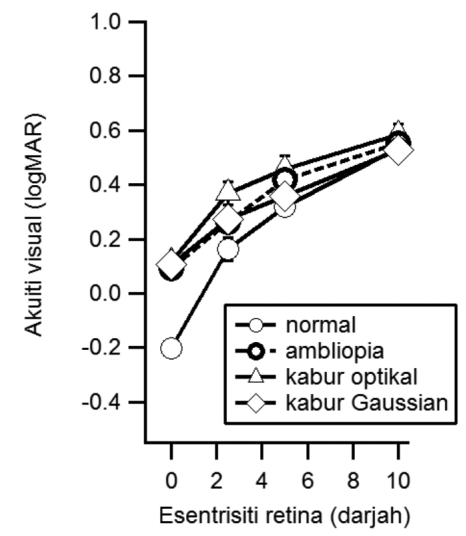

RAJAH 6. Akuiti visual (unit logMAR) diplot melawan esentrisiti retina (unit darjah) bagi subjek normal (daripada Uji Kaji 1) dan subjek normal yang dikaburkan secara optik, subjek normal dikaburkan dengan penuras digital Gaussian dan subjek ambliopia anisometropik

ditetapkan sebagai kriteria inklusi untuk memastikan sebarang kanta yang digunakan mempunyai kesan yang serupa terhadap penglihatan fovea dan periferi subjek. Selain itu, pergerakan mata subjek boleh dijejak dengan menggunakan penjejak mata untuk mengkaji sumbangan pergerakan mata dalam mempengaruhi kesan kesesakan dalam kalangan subjek normal dan subjek ambliopia.

\section{KESIMPULAN}

Ambliopia anisometriopik menunjukkan zon interaksi ruang tidak simetri yang serupa dengan zon interaksi ruang untuk subjek berpenglihatan normal. Kecuali di fovea, kesan kesesakan yang lebih besar didapati untuk rangsangan yang disusun secara jejarian kepada titik fiksasi. Ini juga menyebabkan jarak kesan kesesakan subjek ambliopia meningkat apabila dikur di fovea. Walau bagaimanapun, prestasi akuiti periferi subjek ambliopia tidak berbeza secara signifikan apabila dibandingkan dengan periferi subjek normal.

\section{RUJUKAN}

Atchison, D.A., Pritchard, N., Schmid, K.L., Scott, D.H., Jones, C.E. \& Pope, J.M. 2005. Shape of the retinal surface in emmetropia and myopia. Investigative Ophthalmology and Visual Science 46(8): 2698-2707. doi:10.1167/iovs.04-1506.

Bjork, E.L. \& Murray, J.T. 1977. On the nature of input channels in visual processing. Psychological Review 84(5): 472-484.

Bouma, H. 1970. Interaction effects in parafoveal letter recognition. Nature 226(5241): 177-178. doi:10.1038/226177a0.

Brainard, D.H. 1997. The psychophysics toolbox. Spatial Vision 10(4): 433-436. doi:10.1163/156856897X00357.

Ciuffreda, K., Levi, D. \& Selenow, A. 1991. Amblyopia: Basic and Clinical Aspects. Boston: Butterworth-Heinemann.

Felisberti, F.M., Solomon, J.A. \& Morgan, M.J. 2005. The role of target salience in crowding. Perception 34(7): 823-833. doi:10.1068/p5206.
Feng, C., Jiang, Y. \& He, S. 2007. Horizontal and vertical asymmetry in visual spatial crowding effects. Journal of Vision 7(2): 13.1-10. doi:10.1167/7.2.13.

Flom, M.C., Weymouth, F.W. \& Kahneman, D. 1963. Visual resolution and contour interaction. Journal of the Optical Society of America 53(9): 1026. doi:10.1364/ JOSA.53.001026.

Hairol, M.I., Abd-Latif, N.A., Low, P., Lim, W.P., Aik, J.Y. \& Kaur, S. 2015. Effects of foveal and eccentric viewing on the resolution and contrast thresholds of individual letters. Psychology \& Neuroscience 8(2): 183-192. doi:10.1037/ h0101060.

Hairol, M.I., Formankiewicz, M.A. \& Waugh, S.J. 2013. Foveal visual acuity is worse and shows stronger contour interaction effects for contrast-modulated than luminance-modulated Cs. Visual Neuroscience 30(3): 105-120. doi:10.1017/ S0952523813000102.

Hussin, D.A., Omar, R. \& Knight, V.F. 2009. Penyebab masalah penglihatan di kalangan kanak-kanak prasekolah di Daerah Sitiawan, Perak, Malaysia. Sains Malaysiana 38(6): 959-964.

Jacobs, R.J. 1979. Visual resolution and contour interaction in the fovea and periphery. Vision Research 19(11): 1187-1195. doi:10.1016/0042-6989(79)90183-4.

Kaur, S., Azwa, W., Mohd. Fadzil, N. \& Ariffin, A.E. 2011. Patching therapy in patients with strabismic amblyopia and refractive amblyopia. Sains Malaysiana 40(11): 1325-1329.

Levi, D.M. \& Klein, S.A. 1990. Equivalent intrinsic blur in amblyopia. Vision Research 30(12): 1995-2022.

Levi, D.M., Klein, S.A.\& Aitsebaomo, A.P. 1985. Vernier acuity, crowding and cortical magnification. Vision Research 25(7): 963-977. Retrieved from http://www.sciencedirect.com/ science/article/pii/004269898590207X.

Mutti, D.O., Hayes, J.R., Mitchell, G.L., Jones, L.A., Moeschberger, M.L., Cotter, S.A., Kleinstein, R.N., Manny, R.E., Twelker, J.D., Zadnik, K. \& CLEERE Study Group. 2007. Refractive error, axial length, and relative peripheral refractive error before and after the onset of myopia. Investigative Ophthalmology and Visual Science 48(6): 25102519. doi:10.1167/iovs.06-0562.

Parkes, L., Lund, J., Angelucci, A., Solomon, J.A. \& Morgan, M. 2001. Compulsory averaging of crowded orientation signals in human vision. Nature Neuroscience 4: 739-744. doi:10.1038/89532.

Saw, S.M., Chan, Y.H., Wong, W.L., Shankar,A., Sandar, M.,Aung, T., Tan, D.T.H., Mitchell, P. \& Wong, T.Y. 2008. Prevalence and risk factors for refractive errors in the Singapore Malay eye survey. American Academy of Ophthalmology 115: 17131719. doi:10.1016/j.ophtha.2008.03.016.

Strasburger, H., Harvey, L.O. \& Rentschler, I. 1991. Contrast thresholds for identification of numeric characters in direct and eccentric view. Perception \& Psychophysics 49: 495-508. doi:10.3758/BF03212183.

Stuart, J.A. \& Burian, H.M. 1962. A study of separation difficulty. Its relationship to visual acuity in normal and amblyopic eyes. American Journal of Ophthalmology 53: 471-477. Retrieved from http://www.ncbi.nlm.nih.gov/pubmed/13917936.

Tanlamai, T. \& Goss, D. 1979. Prevalence of monocular amblyopia among anisometropes. American Journal of Optometry and Physiological Optics 56(11): 704-715.

Toet,A.\& Levi, D.M. 1992. The two-dimensional shape of spatial interaction zones in the parafovea. Vision Research 32: 13491357. doi:10.1016/0042-6989(92)90227-A. 
Weakley, D.R. 2001. The association between nonstrabismic anisometropia, amblyopia, and subnormal binocularity. Ophthalmology 108: 163-171.

Program Optometri \& Sains Penglihatan

Fakulti Sains Kesihatan

Universiti Kebangsaan Malaysia

Jalan Raja Muda Abdul Aziz

50300 Kuala Lumpur
*Pengarang untuk surat-menyurat; email: izzuddin.hairol@ ukm.edu.my

Diserahkan: 29 Mei 2017

Diterima: 11 Ogos 2017 